\title{
The Effects of Competence-Based, Expressive and Collaborative Service Performance on the B2B Service Relationship
}

\author{
Wenting Zou, Saara A. Brax, Risto Rajala
}

\author{
"Whether the use of complexity research will fundamentally improve firm, \\ performance will depend on the effect on success derived from its application. "
}

Duncan A. Robertson (2004)

\begin{abstract}
Service performance is considered an essential determinant of successful business relationships. It affects the customer's repurchase intentions and, therefore, the continuity of the relationship between the service provider and the customer. Yet, due to the complexity of B2B relationships, service performance is a multi-faceted issue. It includes at least three crucial aspects: competence-based, expressive, and collaborative performance. The present paper investigates the effects of these dimensions on the buyer-supplier relationship and analyzes their mediated impact on customer repurchasing intentions. In so doing, we establish a structural equation model and test multiple hypotheses with a sample of 141 purchasing professionals from 23 countries. The findings indicate that expressive and collaborative service performance are more significant determinants of successful business relationships and influence business relationship continuity more than competence-based service performance. Also, relationship performance was found to fully mediate the links between expressive and collaborative service performance with customer repurchase intentions. The study underscores that service providers can ensure business continuity with their customers by investing in expressive and collaborative service performance.
\end{abstract}

\section{Introduction}

Perception of past service performance plays a pivotal role in customers' repurchase intentions of B2B services. Previous research has shown that customers are more likely to continue business with a service provider they perceive favorably (Hennig-Thurau et al., 2002; Shamsollahi et al., 2020), and that customers' positive perceptions of the service link to stronger customer repurchasing intentions, either directly (Roy \& Butaney, 2014) or through buyer-perceived value (Aitken \& Paton, 2016). Hence, a positive customer perception of service performance is vital for the sustainable business of service providers. It is especially important for complex B2B services that are difficult to evaluate (Briggs \& Grisaffe, 2010).

This study focuses on the impact of service performance on provider-customer relationships, along with customer repurchase intentions. Most empirical studies examining service performance and repurchase intentions are conducted in the business-toconsumer (B2C) context (for example, Antwi, 2021), emphasizing consumer services, retail, hospitality, or online commerce (Tandon et al., 2017). Nevertheless, some studies demonstrate the impact of service performance on the buyer-supplier relationship in the B2B and industrial services context (Doney \& Cannon, 1997; Homburg \& Garbe, 1999). However, a need remains to analyze further the factors influencing B2B service contract renewal because the linkages between service performance, relationship performance, and customers' purchasing continuity intentions in relational B2B service exchanges constitute a complex setting for purchasing decisions (Bolton et al., 2006).

Service providers need to manage their service performance in several areas. First, because customers 


\section{The Effects of Competence-Based, Expressive and Collaborative Service Performance on the B2B Service Relationship Wenting Zou, Saara A. Brax, Risto Rajala}

are significant contributors to the service process in $\mathrm{B} 2 \mathrm{~B}$ services, and the element of co-creation is salient, collaborative performance has a crucial role in the service process and can significantly influence the service relationship. Second, many industrial and B2B services are sophisticated services that require specialized capabilities and competent performance from the providers. Third, successful services characterize expressive performance, which implies the parties' satisfaction with their interaction throughout the service activities, both on psychological and emotional levels. Further investigation of the complexity of service performance is needed to understand how the different aspects of service performance contribute to the continuity of B2B business relationships.

The following research question was posed for the study: How do service performance and business relationship performance affect service contract renewal? We studied this question by examining the interrelationships between service performance, relationship performance, and customer repurchase intentions through a structural equation modeling (SEM) approach. In the research model, service performance was divided into three dimensions: competence-based, expressive, and collaborative service performance. Hypotheses were tested by analyzing a sample of responses from 141 purchasing professionals in 23 countries. A survey questionnaire was developed and carefully tested to collect the data. The study contributes to the service literature by analyzing the influences of three dimensions of B2B service performance on the business relationship and customers' repurchase intentions.

\section{Theory and hypotheses}

\subsection{Relationship continuity - repurchase intentions}

Customer repurchase intention (or likelihood-to-renew the relationship) is often considered as the eventually positive outcome of the supplier and buyer relationship (Shamsollahi et al., 2020). In this sense, repurchasing intentions refer to the buyer's intent to purchase the same or additional services from the same provider, and thus continue the relationship. It can also reflect the buyer's reluctance to switch suppliers. Repurchasing intentions often consist of contract renewals and increased patronage, typically developing into a longterm business relationship (Cannon \& Homburg, 2001). In $\mathrm{B} 2 \mathrm{~B}$ services, a long-term relationship between buyers and service providers facilitates collaborative innovation for the benefit of both parties.

\subsection{Relationship performance}

Relationship performance reflects the customer's perception of the buyer and supplier relationship (Palmatier et al., 2007). In B2B contexts, the service complexity, long time horizon of delivery, and unfamiliarity of outcomes, increase uncertainties for buying companies (Huo et al., 2016). A good interorganizational relationship between the buyer and service supplier increases mutual understanding and facilitates adaptations during the service process, decreasing buyer-perceived uncertainty (Roehrich \& Lewis, 2014). Although relationship performance is a composite construct that includes several different perspectives, researchers have identified that trust, satisfaction, and commitment form the critical dimensions of relationship performance (Morgan \& Hunt, 1994; Barry \& Doney, 2011). In the following, these components are elaborated in more detail.

Trust in B2B settings refers to the belief of a party that its needs can be met by the actions of another organization (Doney et al., 2007). Hence, trust is a crucial determinant of successful business relationships. The complexity of B2B services and relational exchange makes trust even more critical because it reduces customer-perceived risks during service interaction (Doney et al., 2007).

Satisfaction has been defined as the buyer's positive affective state in a business relationship resulting from the appraisal of their relationship with the supplier (Selviaridis \& Spring, 2007). Smeltzer and Ogden (2002) suggest that it reflects an evaluation of the supplier's overall performance, considering all service episodes instead of focusing on a single transaction. In B2B service exchanges, the process-based and long-term collaboration orientations between the two parties mean that a satisfactory business relationship is critical.

Commitment refers to the buyer's perception of the provider's willingness to maintain a stable relationship in the long run. Different dimensions of commitment, including affective and calculative commitment (Briggs \& Grisaffe, 2010; Stauss et al., 2010), exist due to various motivations to continue the relationship. Affective commitment is the desire to maintain the relationship because the buyer has positive feelings for the supplier and may experience a sense of belonging and loyalty in the relationship (Morgan \& Hunt, 1994). A buyer's calculative commitment implies the need for 


\section{The Effects of Competence-Based, Expressive and Collaborative Service Performance on the B2B Service Relationship Wenting Zou, Saara A. Brax, Risto Rajala}

relationship continuity, for example, due to substantial switching costs or termination costs associated with leaving the relationship (Stauss et al., 2010). Hence, commitment is critical to organizational buying behaviour in relational exchanges. Existing studies show that the buyer's trust in a service provider and satisfaction in the relationship positively influence the buyer's service repurchase intentions (Zeithaml et al., 1996; Doney \& Cannon, 1997; Eggert \& Ulaga, 2002). Studies have shown a strong positive correlation between buyer-perceived commitment and relationship continuity (Morgan \& Hunt, 1994). Hence, we hypothesize:

H1: Relationship performance has a positive direct effect on customer repurchase intentions.

\subsection{Service performance}

Customer-perceived service performance is connected with value-creating practices between customers and service providers. Because customers subjectively determine the value of a service based on their experience, customer perception of service performance is key to understanding and measuring the value realized through a service (Vargo \& Lusch, 2011; Kohtamäki \& Rajala, 2016). In supply chain management research, service performance is commonly evaluated instead of service quality (Stank et al., 2003; Briggs \& Grisaffe, 2010). The dimensions of service performance are based on service quality conceptualizations by Parasuraman et al. (1985) and Grönroos (1984), which include the technical outcomes of a service and its functional processes. The complexity of B2B services requires the assessment and management of multiple parameters to ensure effective service delivery. Hence, we identify three service performance dimensions: competence-based service performance, expressive service performance, and collaborative service performance, which separately examine these dimensions' effects. Understanding these dimensions of service performance helps providers allocate their resources effectively and clarifies decision-making related to purchasing business services (Arnott et al., 2007; Briggs \& Grisaffe, 2010). The following section elaborates on each dimension.

\subsubsection{Competence-based service performance}

Competence-based service performance refers to the outcome-achievement of a service grounded on Grönroos' (1984) widely used concept of "technical service quality". Essentially, it describes "what" the customer gains from interacting with the service provider (for example, service-need fit, conformance to specifications, and reliability of operations) (Arnott et al., 2007). Thus, competence-based service performance extends the outcome-focused technical quality concept with service reliability, defined as accurate and reliable delivery of the promised service outcome (Johnston et al., 2004).

The competence-based service performance dimension focuses on activities that constitute the provider's core services (Lindberg \& Nordin, 2008). Here, expectations are either based on predefined and formally agreed performance criteria or guided by less formal descriptions of the service offering that facilitate the buying decision, since the core service is the reason that initiates the service exchange. Buyers can therefore often measure competence-based service performance based on this fact. In B2B service contexts, measuring competence-based service performance requires buyers to assess the service reliability in terms of how well the service outcome conforms to expectations (Beltagui \& Candi, 2018).

When business customers receive the expected service, the logical outcome is a good inter-organizational relationship between the customer and provider. The literature documents corresponding relationships between expected service outcomes and the three dimensions of relationship performance: trust, satisfaction, and commitment. Prior studies have identified that expected outcomes lead to the buying organization's trust in the service provider (Homburg \& Garbe, 1999). Moreover, previous studies have proven that the outcome-related performance of services positively influences customer satisfaction (Homburg \& Garbe, 1999; Roy \& Butaney, 2014) and can lead to a buyer's commitment to the business relationship (Chumpitaz Caceres \& Paparoidamis, 2007). These considerations lead to the following hypothesis:

H2: Competence-based service performance positively influences relationship performance.

\subsubsection{Expressive service performance}

Expressive service performance concerns the customer's affective reaction to a service. It demonstrates that the service process has characteristics that convey something to the customer on a psychological or emotional level and evokes affective responses (Beltagui \& Candi, 2018). Although these reactions include a subjective component, they reflect the customers' experiences of interactions with the provider, thereby 


\section{The Effects of Competence-Based, Expressive and Collaborative Service Performance on the B2B Service Relationship Wenting Zou, Saara A. Brax, Risto Rajala}

essentially contributing to the broader perception of the service by the customer (Doney et al., 2007).

The affective and experience-centric dimensions of service performance have been captured in various forms in the classical service assessment frameworks, including the SERVQUAL instrument (Parasuraman et al., 1985). The SERVQUAL instrument addresses the service experience with five dimensions: tangibility, reliability, responsiveness, empathy, and assurance. Expressive service performance captures three of them responsiveness, empathy, and assurance, which represent functional service quality as identified by Grönroos (1984). Hence, expressive performance also covers the service provider's support for the customer (Grönroos, 1984; Chumpitaz Caceres \& Paparoidamis, 2007).

Researchers have found positive links between expressive service performance, customer trust, and satisfaction in the relationship (Morgan \& Hunt, 1994; Doney et al., 2007). In a study of industrial services, Homburg and Garbe (1999) illustrate that a customer's trust, satisfaction, and perceived commitment are all positively affected by expressive performance (operationalizes as "process-related quality"). These arguments on expressive service performance give rise to the following hypothesis:

H3: Expressive service performance positively influences relationship performance.

\subsubsection{Collaborative service performance}

Collaborative service performance is the customerperceived performance of collaborating with the service provider during a service exchange, which involves activities and exchange of information to achieve a targeted performance level. In B2B contexts, services are generally co-created through interactions between buyers and suppliers, which requires close collaboration to design, develop, and deliver services (Vargo \& Lusch, 2011). Recent empirical studies highlight information sharing as the foundation of cooperation between buyers and suppliers to improve performance (Barratt, 2004). Collaborative performance of B2B services is often estimated by the information sharing, flexibility, and cooperative attitude of suppliers towards the contract (Barratt, 2004; Guo \& Ng, 2011).

One of the foundational arguments in the servicedominant perspective (Vargo \& Lusch, 2011) is that all services are co-created. Collaboration fosters a relationship between parties with common goals (Guo \& $\mathrm{Ng}, 2011)$. More precisely, transparent information exchange (De Vries et al., 2014) can increase trust and reduce information asymmetry between parties. Yet, the literature review by Oertzen et al. (2018) pointed out that the ways and intensity of sharing and co-creation vary between different types of service offerings and across service life-cycles. Also, a provider's flexibility that facilitates adaptating to unforeseeable situations and promotes a measured approach to problem-solving can increase customer-perceived commitment to the relationship (Guo \& Ng, 2011). Hence, we hypothesize that collaborative service performance, in general, contributes to relationship performance as follows:

H3: Collaborative service performance positively influences relationship performance.

The main argument for distinguishing between competence-based, expressive, and collaborative performance is that assessments of service performance can emphasize outcomes, affection, or cooperation. Research of B2C services demonstrates that service performance is directly linked with customer repurchase intentions (Bolton et al., 2006). Good collaborative buyer-supplier relationships are crucial, particularly in complex services, which are co-designed and produced jointly. According to Caruana (2002), the link between service performance and repurchase intentions is fully mediated by customer satisfaction.

Conversely, if the buyer perceives the underlying relationship as poorly performing, it is unlikely that a repurchasing decision will be made. Briggs \& Grisaffe (2010) conclude that customer trust mediates the influence of service performance on behavioral intentions in B2B contexts. Their findings suggest that service performance has only an indirect impact on B2B repurchase intentions. Hence, it is reasonable to assume that relationship performance mediates the effect of service performance on customer repurchase intentions.

In this study, we examine the outcome-achievement, affective and collaborative aspects of service performance. Undeniably, the relational aspects of service performance are accentuated in long-term collaboration. Thus, we hypothesize that the contributions of all three dimensions of service performance to customer repurchase intentions will be fully mediated by relationship performance. 


\section{The Effects of Competence-Based, Expressive and Collaborative Service Performance on the B2B Service Relationship Wenting Zou, Saara A. Brax, Risto Rajala}

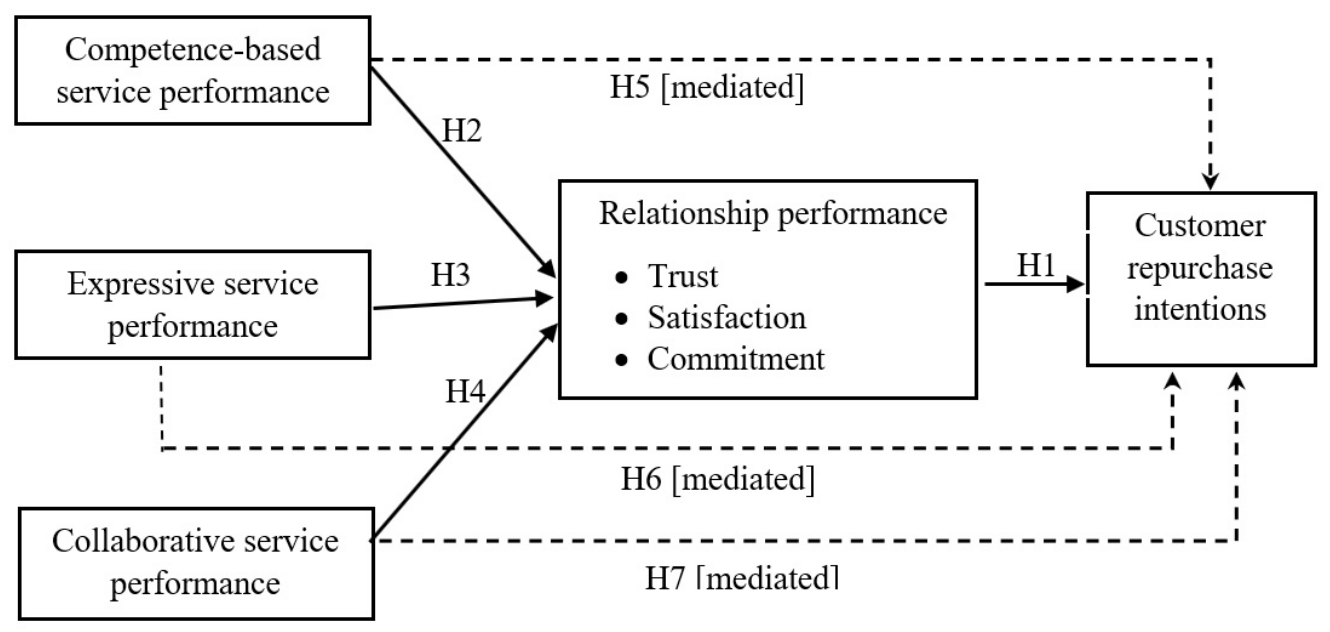

Figure 1. Research Model

H5: Relationship performance fully mediates the positive relationship between competence-based service performance and customer repurchase intentions.

H6: Relationship performance fully mediates the positive relationship between expressive service performance and customer repurchase intention.

H7: Relationship performance fully mediates the positive relationship between collaborative service performance and customer repurchase intention.

The relationships hypothesized above are presented in Figure 1.

\section{Research method}

\subsection{Sample and data collection}

The sampling frame of the present study entailed service purchasing professionals whose jobs involve buying business services. We invited respondents from several countries, industries, levels, and functions for a comprehensive analysis of the phenomenon. As the world's largest professional network (Bonsón \& Bednárová, 2013), we utilized LinkedIn to identify purchasing professionals as potential respondents for the study. LinkedIn focuses on professional content produces informative individual and organizational profiles, which can be used to identify experts in producing research data (Maramwidze-Merrison, 2016). We selected special interest groups of purchasing professionals to share their experiences, expertise, and knowledge in a supportive learning environment. These groups were considered as an effective way to approach professionals experienced in purchasing B2B services.

LinkedIn's private special interest groups for professional purchasing were used to establish the contact list we used to gain a customer-perceived view of service performance, and its effects on repurchasing. These groups are professional interest groups in which members share information and discuss topical issues in professional purchasing. Membership in the special interest group requires an application and is controlled by the group owner, thus improving the quality of sampling over other social media. The two largest international purchasing private groups were selected as the contact database: Purchasing \& Materials Management

(https://www.linkedin.com/groups/156598) and Purchasing \& Global Supply Chain Professionals (https://www.linkedin.com/groups/50589).

For the initial contact list, we randomly selected a sample of 1,000 individuals from the lists of members of these two groups. We used several techniques to search e-mail addresses, including Google Search and company websites. If a person's contact information was not found on the internet, it was replaced by someone else from these groups. The contact list included 1,000 individuals from 46 countries. This was thus not an entirely random sample, which is a limitation of the study. However, due to the multiindustry context and the large size of the forum groups, we concluded that the members would not likely be more connected than people typically are in an industry. 


\section{The Effects of Competence-Based, Expressive and Collaborative Service Performance on the B2B Service Relationship Wenting Zou, Saara A. Brax, Risto Rajala}

We sent potential respondents an e-mail message, including a cover letter and the link to our web survey. Two reminder invitations were sent during our data collection phase. Of the 1,000 prospective informants, 48 were not able to receive surveys due to incorrect or outdated contact information. 55 respondents asked to be removed from the sample (either because they were no longer responsible for service purchasing or because they declined to participate), leaving an effective sample of 897 individuals. During the data collection period between August to October 2015, 141 usable responses from 23 countries were received, for an effective response rate of $15.7 \%$. This falls within the range from $6 \%$ to $16 \%$ which Dillman (2000) considers acceptable for international internet surveys. Most of the respondents had approximately ten years of purchasing experience in organizations.

\subsection{Survey development and measures}

Survey items used in this study were derived from measures represented in the literature and then refined through a series of pre-tests. The questionnaire was tested by a marketing researcher specialized in questionnaire design and with a sample of 18 professionals representing purchasing and business functions in public, private, and non-profit organizations. These organizations cover several industries containing utilities, information services, manufacturing, and educational services.

All constructs were measured with the typical reflective view of construct specification. From the original 24item instruments, two items were removed based on construct reliability and validity tests. All items were measured using 5-point Likert scales with anchors of (1) strongly disagree to (5) strongly agree, as summarized in Table 1. The respondents were asked to evaluate their most recent purchase. Thus, the responses measure different areas of service performance and relationship performance in a single, dyadic business relationship in their responses with a specific B2B service provider company.

We chose structural equation modeling (SEM) to test the research model. Following Hair et al. (2006), our sample size made SEM a feasible method to test the hypotheses.

\subsection{Measurement reliability and validity}

As suggested by Anderson \& Gerbing (1988), we conducted a procedure for scale development before estimating the structural path to test hypothesized relationships (Tables 2 and 3). First, we estimated items by confirmatory factor analysis, using Stata/MP 13 with maximum likelihood estimation. All items met the criterion for standardized factor loadings (above 0.5) as suggested by Bagozzi \& Yi (1988). We tested the reliability of the measurement using Cronbach's $\alpha$. All of Cronbach's $\alpha$ coefficients exceed 0.7 (Table 3), which provides reliability (Fornell \& Larcker, 1981). Furthermore, the average variance extracted (AVE) for each construct was above 0.5, which supports convergent validity as recommended by Fornell \& Larcker (1981). The AVE for each construct was higher than the squared correlation between all pairs involving the construct, providing discriminant validity (Fornell \& Larcker, 1981), shown in Table 3. Consequently, all of the constructs demonstrate good reliability and validity.

\section{Results}

\subsection{Description of respondents}

The sample consisted of experts in service purchasing within companies across a wide range of industries. Table 4 shows the sample's demographic properties. The respondents covered 17 out of 18 industries in our sampling frame (except the arts, entertainment and recreation industry), which follows the North American Industry Classification System (NAICS) (United States Census Bureau, 2014). Also, as illustrated in Table 4, 121 respondents represented the purchasing function, while 20 respondents represented other functions, but had strong interest in purchasing. Most of the 121 respondents that represented the purchasing function in their organizations were middle- or senior-level managers. The average experience of purchasing function respondents was 12.8 years, with 13.8 years for those in other functions. The respondents' extensive experience in $\mathrm{B} 2 \mathrm{~B}$ purchasing in many industries and countries made their responses both valuable and relevant to the survey.

\subsection{Results of hypotheses testing}

The hypotheses were tested by SEM and with three structural equation models. Model 1 was established to test H1-H4. Models 1, 2, and 3 together were estimated to test the fully mediated influences $\mathrm{H} 5-\mathrm{H} 7$. The results of the modeling estimations and associated fit statistics are demonstrated in Table 5.

Based on the results of model 1, H1-H4 were supported. Strong support was shown for the positive impact of relationship performance on customer repurchase intentions, thereby supporting $H 1 \quad(\beta=0.75, p<0.001)$. 


\section{The Effects of Competence-Based, Expressive and Collaborative Service Performance on the B2B Service Relationship Wenting Zou, Saara A. Brax, Risto Rajala}

Table 1. Measurement Scales

\begin{tabular}{|c|c|c|c|}
\hline Construct & Abbr. & Item & Source \\
\hline $\begin{array}{l}\text { Competence- } \\
\text { based service } \\
\text { performance }\end{array}$ & $\begin{array}{l}\operatorname{csP} 1 \\
\operatorname{csP} 2 \\
\operatorname{csp} 3\end{array}$ & $\begin{array}{l}\text { The supplier has efficient processes for } \\
\text { dealing with our service requests. } \\
\text { The supplier's service personnel can } \\
\text { handle our requests. } \\
\text { The supplier always delivers the service } \\
\text { on time. }\end{array}$ & $\begin{array}{l}\text { (Parasuraman } \\
\text { et al., 1988; } \\
\text { Homburg \& } \\
\text { Garbe, 1999) }\end{array}$ \\
\hline $\begin{array}{l}\text { Expressive } \\
\text { service } \\
\text { performance }\end{array}$ & $\begin{array}{l}\text { ESP1 } \\
\text { ESP2 } \\
\text { ESP3 }\end{array}$ & $\begin{array}{l}\text { The supplier's personnel show that they } \\
\text { value us. } \\
\text { We believe this supplier considers how } \\
\text { their decisions and actions influence us. } \\
\text { When it comes to things that are } \\
\text { important to us, we could count on this } \\
\text { supplier's support. }\end{array}$ & $\begin{array}{l}\text { (Parasuraman } \\
\text { et al., 1988; } \\
\text { Homburg \& } \\
\text { Garbe, 1999) }\end{array}$ \\
\hline $\begin{array}{l}\text { Collaborative } \\
\text { service } \\
\text { performance }\end{array}$ & $\begin{array}{l}\text { CBSP1 } \\
\text { CBSP2 } \\
\text { CBSP3 }\end{array}$ & $\begin{array}{l}\text { This supplier is flexible enough to handle } \\
\text { unforeseen problems. } \\
\text { The supplier honors our contract in } \\
\text { practice. } \\
\text { This supplier openly shares information } \\
\text { with us. }\end{array}$ & $\begin{array}{l}\text { (Homburg \& } \\
\text { Garbe, 1999; } \\
\text { Guo \& Ng, } \\
\text { 2011) }\end{array}$ \\
\hline $\begin{array}{l}\text { Relationship } \\
\text { performance }\end{array}$ & & & \\
\hline $\begin{array}{l}\text { Customer trust } \\
\text { in relationship }\end{array}$ & $\begin{array}{l}\text { CT1 } \\
\text { CT2 } \\
\text { CT3 } \\
\text { CT4 }\end{array}$ & $\begin{array}{l}\text { The supplier's promises are always } \\
\text { reliable. } \\
\text { The supplier is not always honest with us. } \\
\text { (Reverse) } \\
\text { The supplier is truly concerned about our } \\
\text { business success. } \\
\text { We are confident that this supplier } \\
\text { always keeps our best interests in mind. }\end{array}$ & $\begin{array}{l}\text { (Doney \& } \\
\text { Cannon, } \\
\text { 1997; Doney } \\
\text { et al., 2007) }\end{array}$ \\
\hline $\begin{array}{l}\text { Customer } \\
\text { satisfaction in } \\
\text { relationship }\end{array}$ & $\begin{array}{l}\operatorname{cs} 2 \\
\operatorname{cs} 3\end{array}$ & $\begin{array}{l}\text { The service provided by the supplier } \\
\text { meets our expectations. } \\
\text { The time of service delivery meets our } \\
\text { expectations. } \\
\text { Compared with alternative suppliers, we } \\
\text { are confident that this supplier will better } \\
\text { help us achieve our goal. } \\
\text { We are willing to recommend the } \\
\text { supplier without any reservation. }\end{array}$ & $\begin{array}{l}\text { (Homburg \& } \\
\text { Garbe, 1999; } \\
\text { Roberts et al., } \\
\text { 2003) }\end{array}$ \\
\hline $\begin{array}{l}\text { Customer } \\
\text { commitment } \\
\text { in relationship }\end{array}$ & $\begin{array}{l}\mathrm{CC} 1 \\
\mathrm{CC} 2\end{array}$ & $\begin{array}{l}\text { Our firm is willing to invest in the } \\
\text { relationship to make it successful. } \\
\text { Because of our history, we are loyal to } \\
\text { this supplier. }\end{array}$ & $\begin{array}{l}\text { (Homburg \& } \\
\text { Garbe, 1999; } \\
\text { Doney et al., } \\
\text { 2007) }\end{array}$ \\
\hline
\end{tabular}




\section{The Effects of Competence-Based, Expressive and Collaborative Service Performance on the B2B Service Relationship Wenting Zou, Saara A. Brax, Risto Rajala}

Table 1. Measurement Scales (cont'd)

\begin{tabular}{lcll}
\hline $\begin{array}{l}\text { Repurchase } \\
\text { intentions }\end{array}$ & RI1 & $\begin{array}{l}\text { We expect to continue doing business } \\
\text { with the current supplier over the next } \\
\text { few years. }\end{array}$ & $\begin{array}{l}\text { (Eggert \& } \\
\text { Ulaga, 2002; } \\
\text { Barry \& } \\
\text { We keep searching alternatives to avoid } \\
\text { dependence on this supplier. (Reverse) } \\
\text { RI2011) }\end{array}$ \\
& RI3 & $\begin{array}{l}\text { Our intention is to continue with this } \\
\text { supplier as long as possible. }\end{array}$ & \\
\hline
\end{tabular}

Table 2. Constructs and Measurement Items

\begin{tabular}{lllll}
\hline Construct & $\begin{array}{l}\text { Item } \\
\text { name }\end{array}$ & Loading & Mean & SD \\
\hline Competence-based service performance & CSP1 & 0.85 & 3.91 & 0.66 \\
(AVE $=0.62, \alpha=0.84$ ) & CSP2 & 0.85 & 3.93 & 0.68 \\
& CSP3 & 0.65 & 3.58 & 0.70 \\
Expressive service performance & ESP1 & 0.77 & 3.92 & 0.68 \\
(AVE $=0.61, \alpha=0.85)$ & ESP2 & 0.77 & 3.71 & 0.68 \\
& ESP3 & 0.81 & 3.78 & 0.73 \\
Collaborative service performance & CBSP1 & 0.75 & 3.79 & 0.72 \\
(AVE $=0.53, \alpha=0.81$ ) & CBSP5 & 0.74 & 3.83 & 0.69 \\
& CBSP6 & 0.70 & 3.67 & 0.64 \\
Relationship quality & & & & \\
Customer trust in relationship & CT1 & 0.81 & 3.47 & 0.72 \\
(AVE $=0.65, \alpha=0.89)$ & CT2 & 0.80 & 3.64 & 0.80 \\
& CT3 & 0.82 & 3.54 & 0.78 \\
& CT4 & 0.81 & 3.36 & 0.72 \\
Customer satisfaction in relationship & CS1 & 0.84 & 3.94 & 0.59 \\
(AVE $=0.58, \alpha=0.85$ ) & CS2 & 0.76 & 3.87 & 0.67 \\
& CS3 & 0.69 & 3.79 & 0.65 \\
& CS4 & 0.72 & 3.60 & 0.72 \\
Customer commitment in relationship & CC1 & 0.76 & 3.39 & 0.74 \\
(AVE $=0.58, \alpha=0.81$ ) & CC2 & 0.76 & 3.04 & 0.81 \\
Repurchase intentions & RI1 & 0.76 & 3.67 & 0.67 \\
(AVE $=0.53, \alpha=0.80$ ) & RI2 & 0.72 & 3.38 & 0.68 \\
& RI3 & 0.71 & 3.28 & 0.72 \\
\hline
\end{tabular}

Furthermore, all three dimensions of service performance had significant positive impacts on relationship performance, which supports $\mathrm{H} 1(\beta=0.16$, $\mathrm{p}<0.01), \mathrm{H} 2(\beta=0.23, \mathrm{p}<0.01)$, and H3 $(\beta=0.30, \mathrm{p}<0.001)$ respectively. According to the Chow test (Chow, 1960), the independent variable with a greater coefficient also has greater impacts on the dependent variable. Based on the coefficients, collaborative service performance plays a greater role in relationship performance than competence-based service performance and expressive service performance.

To test $\mathrm{H} 5-\mathrm{H} 7$, involving the mediated influences of three dimensions of service performance on customer repurchase intentions, an adapted version of Baron and Kenny (1986) procedure was applied following Briggs and Grisaffe (2010). Four conditions are required to support full mediation. First, the independent variable must significantly affect the mediator. Second, the mediator must significantly affect the dependent variable. Third, the independent variable must significantly influence the dependent variable when the mediator is removed from the model. Last, for full mediation to be supported, the direct path from the independent variable to the dependent variable must become non-significant when the mediator is returned 


\section{The Effects of Competence-Based, Expressive and Collaborative Service Performance on the B2B Service Relationship Wenting Zou, Saara A. Brax, Risto Rajala}

Table 3. Discriminant Validity Test from Average Variance Extracted

\begin{tabular}{|c|c|c|c|c|c|c|c|}
\hline Construct & 1 & 2 & 3 & 4 & 5 & 6 & 7 \\
\hline $\begin{array}{l}\text { 1. Competence-based service } \\
\text { performance }\end{array}$ & 0.62 & & & & & & \\
\hline 2. Expressive service performance & $\begin{array}{l}0.38^{*} \\
*\end{array}$ & 0.61 & & & & & \\
\hline $\begin{array}{l}\text { 3. Collaborative service } \\
\text { performance }\end{array}$ & $\begin{array}{l}0.36^{*} \\
*\end{array}$ & $\begin{array}{l}0.50^{*} \\
*\end{array}$ & 0.53 & & & & \\
\hline 4. Customer trust in relationship & $\begin{array}{l}0.39 * \\
*\end{array}$ & $\begin{array}{l}0.45^{*} \\
*\end{array}$ & $\begin{array}{l}0.44^{*} \\
*\end{array}$ & 0.65 & & & \\
\hline $\begin{array}{l}\text { 5. Customer satisfaction in } \\
\text { relationship }\end{array}$ & $\begin{array}{l}0.42^{*} \\
*\end{array}$ & $\begin{array}{l}0.48^{*} \\
*\end{array}$ & $\begin{array}{l}0.47^{*} \\
*\end{array}$ & $\begin{array}{l}0.48^{*} \\
*\end{array}$ & 0.58 & & \\
\hline $\begin{array}{l}\text { 6. Customer commitment in } \\
\text { relationship }\end{array}$ & $0.02^{*}$ & $\begin{array}{l}0.09^{*} \\
*\end{array}$ & $\begin{array}{l}0.11^{*} \\
*\end{array}$ & $\begin{array}{l}0.10^{*} \\
*\end{array}$ & $\begin{array}{l}0.08^{*} \\
*\end{array}$ & 0.58 & \\
\hline 7. Repurchase intentions & $\begin{array}{l}0.13^{*} \\
*\end{array}$ & $\begin{array}{l}0.20^{*} \\
*\end{array}$ & $\begin{array}{l}0.24^{*} \\
*\end{array}$ & $\begin{array}{l}0.23^{*} \\
*\end{array}$ & $\begin{array}{l}0.32^{*} \\
*\end{array}$ & $\begin{array}{l}0.21 * \\
*\end{array}$ & 0.53 \\
\hline
\end{tabular}

Note: ${ }^{*} \mathrm{p}<0.05,{ }^{* *} \mathrm{p}<0.01$

The bold diagonal entries show the average variance extracted by the construct, while the off-diagonal entries show the squared correlation between constructs. Source: Fornell \& Larcker (1981)

to the model. Therefore, model 1 was estimated to test the first two conditions, model 2 was estimated to test the third condition, and model 3 was estimated to test the final condition.

In model 2, the direct effect of competence-based service performance on repurchase intentions was not significant $(\beta=0.07, p>0.05)$. Therefore, it did not meet the third condition of full mediation, rejecting H5. In terms of H6, all four conditions were supported. Model 1 demonstrated that expressive service performance has significant impacts on relationship performance and that relationship performance has significant impacts on customer repurchase intentions. Model 2 confirmed that the direct path from expressive service performance to customer repurchase intentions is significant and positive $(\beta=0.11, \quad \mathrm{p}<0.05)$, when the path from relationship performance to repurchase intentions is constrained to be zero, supporting the third condition.

Our analysis of the Model 3 revealed that the direct path from expressive service performance to repurchase intentions becomes non-significant $(\beta=0.05, p>0.05)$ when the influences of relationship performance were inserted back into the model. These findings confirm that relationship performance fully mediates the relationship between expressive service performance and customer repurchase intentions, confirming H6. As for $\mathrm{H} 7$, all four conditions were also supported. Model 1 represented that the first two conditions were met. Model 2 confirmed that the direct path from collaborative service performance to customer repurchase intentions is significant and positive $(\beta=0.36$, $\mathrm{p}<0.01$ ), when the path from relationship performance to repurchase intentions is constrained to be zero, supporting the third condition. Model 3 found that the direct path from collaborative service performance to repurchase intentions becomes non-significant $(\beta=0.15$, $\mathrm{p}>0.05)$ when the influences of relationship performance were inserted back into the model. Collectively, these findings confirm that relationship performance fully mediates the relationship between collaborative service performance and customer repurchase intentions, confirming $\mathrm{H} 7$.

\section{Discussion and Conclusions}

Extending the explanatory power of service performance theories beyond their original $\mathrm{B} 2 \mathrm{C}$ service contexts into analyzing the B2B services calls for further investigations that consider the combined effects of various service dimensions on service performance in the customer-provider relationship, and ultimately, on customers' repurchase intentions. This study is among the first to examine how both service performance and relationship performance influence repurchase intentions in B2B services. The data covers a wide range of industries, thereby supplementing the pre-existing studies that have focused on specific sectors and phases in buyer decision making (Bolton et al., 2006).

\subsection{Theoretical implications}

Empirical research examining buyer-supplier relationship performance in B2B contexts has often 


\section{The Effects of Competence-Based, Expressive and Collaborative Service Performance on the B2B Service Relationship Wenting Zou, Saara A. Brax, Risto Rajala}

Table 4. Descriptive statistics of the sample

\begin{tabular}{|c|c|c|c|c|}
\hline Respondent position & $\begin{array}{c}\text { Purchasing } \\
\text { function }\end{array}$ & $\begin{array}{c}\text { Other } \\
\text { function }\end{array}$ & $\mathbf{N}$ & Share \\
\hline Executive & 4 & 7 & 11 & $7.8 \%$ \\
\hline SVP or VP & 9 & 1 & 10 & $7.09 \%$ \\
\hline Director & 28 & 4 & 32 & $22.70 \%$ \\
\hline Manager or Team leader & 62 & 3 & 65 & $46.1 \%$ \\
\hline Expert, Specialist or & 17 & 5 & 22 & $15.6 \%$ \\
\hline Assistant or Coordinator & 1 & 0 & 1 & $0.71 \%$ \\
\hline Total & 121 & 20 & 141 & $100 \%$ \\
\hline $\begin{array}{l}\text { Average purchasing } \\
\text { experience (years) }\end{array}$ & 12.8 & 13.8 & 12.9 & \\
\hline \multicolumn{3}{|l|}{ Industry } & $\begin{array}{l}\text { Number of } \\
\text { respondents }\end{array}$ & Percentage \\
\hline \multicolumn{3}{|l|}{ Manufacturing } & 51 & $36.17 \%$ \\
\hline \multicolumn{3}{|c|}{ Health care and social assistance } & 14 & $9.93 \%$ \\
\hline \multicolumn{3}{|c|}{ Information (publishing, telecommunications, all } & 13 & $9.22 \%$ \\
\hline \multicolumn{3}{|c|}{ Professional, scientific and technical services } & 13 & $9.22 \%$ \\
\hline \multicolumn{3}{|c|}{ Other services (except public administration) } & 11 & $7.80 \%$ \\
\hline \multicolumn{3}{|l|}{ Retail trade } & 6 & $4.26 \%$ \\
\hline \multicolumn{3}{|c|}{ Accommodation and food services } & 5 & $3.55 \%$ \\
\hline \multicolumn{3}{|c|}{ Utilities (power, gas, water, sewage, etc.) } & 5 & $3.55 \%$ \\
\hline \multicolumn{3}{|c|}{ Agriculture, forestry, fishing and hunting } & 4 & $2.84 \%$ \\
\hline \multicolumn{3}{|c|}{ Finance and insurance } & 4 & $2.84 \%$ \\
\hline \multicolumn{3}{|c|}{ Transportation and warehousing } & 4 & $2.84 \%$ \\
\hline \multicolumn{3}{|c|}{ Mining, quarrying and oil and gas extraction } & 3 & $2.13 \%$ \\
\hline \multicolumn{3}{|l|}{ Construction } & 2 & $1.42 \%$ \\
\hline \multicolumn{3}{|l|}{ Educational services } & 2 & $1.42 \%$ \\
\hline \multicolumn{3}{|l|}{ Public administration } & 2 & $1.42 \%$ \\
\hline \multicolumn{3}{|c|}{ Real estate and rental and leasing } & 1 & $0.71 \%$ \\
\hline \multicolumn{3}{|l|}{ Wholesale trade } & 1 & $0.71 \%$ \\
\hline \multicolumn{3}{|l|}{ Total (17) } & 141 & $100 \%$ \\
\hline
\end{tabular}

considered service performance as an aggregate construct (Arnott et al., 2007; Briggs \& Grisaffe, 2010). By investigating the three dimensions of service performance - competence-based, expressive, and collaborative - this study found that all three dimensions directly impact relationship performance. This finding demonstrates that the service outcome, the customer's affective reactions, and the collaboration between the customer and their provider during service exchanges are essential in business service exchanges. Compared with competence-based service performance, expressive and collaborative service performance have more substantial effects on business relationships, emphasizing the importance of the service experience as a critical determinant in building inter-organizational relationships. This is consistent with previous studies which demonstrate the value of investing in "soft" services (Chatterjee, 2017).

This result contradicts the finding by Chumpitaz Caceres \& Paparoidamis (2007), which indicated a greater effect of the technical service quality on the relationship satisfaction as compared with the functional service quality. Potential explanations for this include that the complexity of services in the current study might be higher than previously studied, as the growing trend of purchasing business services has become more complex in the markets (Selviaridis et al., 2013). Complexity arises from the diversity of interaction between parties involved in the service 


\section{The Effects of Competence-Based, Expressive and Collaborative Service Performance on the B2B Service Relationship Wenting Zou, Saara A. Brax, Risto Rajala}

delivery, uncertainties of the situation in which the service takes place, and difficulties in evaluating service outcomes (Zou et al., 2018). The increasing level of services complexity is reflected in the supporting processes and resources required, which eventually increases complexity in contemporary business relationships. This indicates a growing importance for collaborative service performance in complex B2B services.
Moreover, the analysis provides an empirical explanation for the supplier selection and continuance rationale of purchasing business services. Similar implications were provided in an earlier study by Lindberg \& Nordin (2008), who demonstrated that the choice of service provider involving complex services is based on "soft" factors, such as the supplier's responsiveness, flexibility, creativity, and ability to cooperate. These factors are consistent with expressive

Table 5. Standardized Estimates and Fit Indices for Structural Equation Modeling

\begin{tabular}{|c|c|c|c|c|c|c|}
\hline & \multicolumn{2}{|c|}{ Model 1} & \multicolumn{2}{|c|}{ Model 2} & \multicolumn{2}{|c|}{ Model 3} \\
\hline & $\begin{array}{c}\text { Co- } \\
\text { efficient }\end{array}$ & Z-value & $\begin{array}{c}\text { Co- } \\
\text { efficient }\end{array}$ & Z-value & $\begin{array}{c}\text { Co- } \\
\text { efficient }\end{array}$ & $\begin{array}{c}\text { Z- } \\
\text { value }\end{array}$ \\
\hline $\begin{array}{l}\text { Estimated path } \\
\text { Competence-based } \\
\text { service performance -> } \\
\text { relationship } \\
\text { performance }\end{array}$ & $0.16^{* *}$ & 2.62 & $0.16^{* *}$ & 2.62 & $0.16^{* *}$ & 2.62 \\
\hline $\begin{array}{l}\text { Expressive service } \\
\text { performance -> } \\
\text { relationship } \\
\text { performance }\end{array}$ & $0.23^{* *}$ & 2.93 & $0.23^{* *}$ & 2.93 & $0.23^{* *}$ & 2.93 \\
\hline $\begin{array}{l}\text { Collaborative service } \\
\text { performance -> } \\
\text { relationship } \\
\text { performance }\end{array}$ & $0.30^{* * *}$ & 3.70 & $0.30^{* * *}$ & 3.70 & $0.30 * * *$ & 4.32 \\
\hline $\begin{array}{l}\text { Competence-based } \\
\text { service performance -> } \\
\text { Repurchase intentions }\end{array}$ & & & 0.07 & 0.78 & -0.04 & -0.45 \\
\hline $\begin{array}{l}\text { Expressive service } \\
\text { performance -> } \\
\text { Repurchase intentions }\end{array}$ & & & $0.11^{*}$ & 2.04 & 0.05 & 0.44 \\
\hline $\begin{array}{l}\text { Collaborative service } \\
\text { performance -> } \\
\text { Repurchase intentions }\end{array}$ & & & $0.36^{* *}$ & 2.87 & 0.15 & 1.28 \\
\hline $\begin{array}{l}\text { Relationship quality -> } \\
\text { Repurchase intentions }\end{array}$ & $0.75^{* * *}$ & 9.66 & & & $0.70^{* * *}$ & 6.04 \\
\hline Fit indices & & & & & & \\
\hline CFI & 1.00 & & 0.96 & & 1.00 & \\
\hline TLI & 1.02 & & 0.91 & & 1.00 & \\
\hline RMSEA & 0.00 & & 0.04 & & 0.00 & \\
\hline $\mathrm{X} 2 /(\mathrm{df})$ & $0.62(2)$ & & $10.74(3)$ & & $0.02(1)$ & \\
\hline CD & 0.55 & & 0.61 & & 0.56 & \\
\hline
\end{tabular}




\section{The Effects of Competence-Based, Expressive and Collaborative Service Performance on the B2B Service Relationship Wenting Zou, Saara A. Brax, Risto Rajala}

and collaborative service performance in this study. Purchasing complex services require continuous interaction and flexibility between the parties, which thus implies the importance of "soft" criteria in supplier selection criteria.

Our analysis revealed that the link between expressive service performance and customer repurchase intentions is fully mediated by relationship performance. Compared with prior findings in B2C contexts, the B2B context appeared to weaken the direct influence of expressive service performance on customer repurchase intentions, while strengthening the indirect impact by generating a mediating role for relationship performance. Customer repurchase intentions depend on the relationship with service providers, rather than emanating directly from expressive service performance. The study also confirmed that relationship performance mediates the relationship between collaborative service performance and customer repurchase intentions. This implies that good inter-organizational relationships are "order qualifiers" for repurchase intentions, whereas strong collaborative service performance represents a potential "order winner".

The recent megatrends in business, such as business process outsourcing (Handley \& Benton Jr., 2009), servitization of product-based businesses (Rajala et al., 2019), the increasing complexity of product services systems (PSS), and the emergence of digital platforms for business, have led to the proliferation and spreading of B2B services beyond traditional service sectors. Service performance has been considered a key contributor to business continuity (Zeithaml et al., 1996), warranting further considerations due to complexity increases to $\mathrm{B} 2 \mathrm{~B}$ services in recent years (Zou et al., 2018).

The present study adds to current knowledge by having identified and analyzed the influence of three dimensions of service performance on relationship performance and customer repurchase intentions in B2B contexts. Expressive and collaborative service performance were shown to be the dominant determinants for successful buyer-supplier relationships. These performance dimensions ultimately translate into customer repurchase intentions through the mediating role of relationship performance. Hence, despite the quite mature discussion on service performance in the literature, this study increases understanding about the determinants of service purchasing decisions in B2B contexts.

\subsection{Managerial implications}

This study offers three practical implications for B2B service exchanges. First, the results suggest that investing in expressive and collaborative service performance is likely to pay off for business continuity. Here, the use of design tools to focus on customer emotions during service delivery (Beltagui \& Candi, 2018) and improve information flow between parties (Barratt, 2004) could be helpful. To cultivate good business relationships with customers, service providers should train service employees on how to deliver services. Service managers can develop ways of interacting with customers to understand their needs better and to monitor and adapt to changes in service delivery.

Second, the impact of mediation implies that relationship performance is indispensable to reap the results from good service performance as a way of maintaining long-term business continuity. This provides strategic guidance for service companies to allocate their resources to both service improvements and relationship management, while ensuring that their companies' service strategies are not solely based on principles that apply to $\mathrm{B} 2 \mathrm{C}$ contexts.

Finally, the findings have implications for organizational buyers. If a purchasing organization desires long-term partnerships with their service provider, especially in complex services, purchasing managers should give more weight to "soft" indicators. Although "soft" criteria may seem particularly difficult to evaluate, buyers can assess provider capabilities based on references and feedback from previous customers.

\subsection{Limitations and avenues for future research}

While the findings are robust, the study has certain limitations that suggest a direction for future research. First, in survey development, the wording and contextual fit of the scale items were examined in interviews and pre-tests. Given that the questionnaire was administered globally, purchasing professionals in different countries might have interpreted the behaviour-related questions differently. Therefore, studies in a global research context should invite people from different countries to further test the questionnaire.

Second, due to the type of dataset, the results need to be 


\section{The Effects of Competence-Based, Expressive and Collaborative Service Performance on the B2B Service Relationship Wenting Zou, Saara A. Brax, Risto Rajala}

interpreted with caution. Although the 1,000 people on the contact list were randomly selected from two purchasing groups on LinkedIn, membership in these purchasing groups are not random. The collected data covered 17 industries from 23 countries, though the distribution of sectors was not equally represented, making generalizability across all industries uncertain. Future studies should examine the research model using a larger and more comprehensive sample, including more equal distribution of various sectors and countries. This would also allow further comparison of results from multiple industries, thereby improving our understanding of making service repurchasing decisions in different organizations.

Finally, future research should introduce control variables into the research model. Variables such as company size and age of relationship may be necessary for B2B service contexts and could help eliminate or explain other possible effects on customer intentions.

\section{References}

Aitken, A., \& Paton, R.A. 2016. Professional Buyers and the Value Proposition. European Management Journal, $34(3)$ : DOI: https://doi.org/10.1016/j.emj.2016.03.004

Anderson, J.C., \& Gerbing, D.W. 1988. Structural Equation Modeling in Practice: A review and recommended two-step approach. Psychological Bulletin, 103(3), 411. DOI: https://doi.org/10.1037/0033-2909.103.3.411

Antwi, S. 2021. "I Just Like this E-Retailer": Understanding online consumers repurchase intention from relationship quality perspective. Journal of Retailing and Consumer Services, 61, 102568.

DOI:

https://doi.org/10.1016/j.jretconser.2021.102568

Doney, P.M., Barry, J.M., \& Abratt, R. 2007. Trust Determinants and Outcomes in Global B2B Services. European Journal of Marketing, 41(9/10): 1096-1116. DOI: https://doi.org/10.1108/03090560710773363

Bagozzi, R.P., \& Yi, Y. 1988. On the Evaluation of Structural Equation Models. Journal of the Academy of Marketing Science, 16(1): 74-94. DOI: https://doi.org/10.1007/bf02723327

Baron, R.M., \& Kenny, D.A. 1986. The Moderator-Mediator Variable Distinction in Social Psychological Research: Conceptual, strategic, and statistical considerations. Journal of Personality and Social Psychology, 51(6), 1173. DOI: https://doi.org/10.1037/0022-3514.51.6.1173
Barratt, M. 2004. Understanding the Meaning of Collaboration in the Supply Chain. Supply Chain Management: an international journal, 9(1): 30-42. DOI: https://doi.org/10.1108/13598540410517566

Barry, J.M., \& Doney, P.M. 2011. Cross-Cultural Examination of Relationship Quality. Journal of Global Marketing, 24(4): 305-323. DOI: https://doi.org/10.1080/08911762.2011.602321

Beltagui, A., \& Candi, M. 2018. Revisiting Service Quality Through the Lens of Experience-Centric Services. International Journal of Operations Production
Management, DOI: https://doi.org/10.1108/IJOPM-06-2015-0339

Bolton, R.N., Lemon, K.N., \& Bramlett, M. 2006. The Effect of Service Experiences Over Time on a Supplier's Retention of Business Customers. Management Science, 52(12): 1811-1823. DOI: https://doi.org/10.1287/mnsc.1060.0594

Bonsón, E., \& Bednárová, M. 2013. Corporate LinkedIn Practices of Eurozone Companies. Online Information 37(6): DOI: https://doi.org/10.1108/OIR-09-2012-0159

Briggs, E., \& Grisaffe, D. 2010. Service PerformanceLoyalty Intentions Link in a Business-to-Business Context: The role of relational exchange outcomes and customer characteristics. Journal of Service Research, 13(1): 37-51. DOI: https://doi.org/10.1177/1094670509345683

Cannon, J.P., \& Homburg, C. 2001. Buyer-Supplier Relationships and Customer Firm Costs. Journal of Marketing, $255(1)$ : DOI: https://doi.org/10.1509/jmkg.65.1.29.18136

Caruana, A. 2002. Service Loyalty: the effects of service quality and the mediating role of customer satisfaction. European Journal of Marketing, 36(7/8): 811-828.

DOI: https://doi.org/10.1108/03090560210430818

deLeon A.J., \& Chatterjee, S.C. 2017. B2B Relationship Calculus: quantifying resource effects in servicedominant logic. Journal of the Academy of Marketing Science, 45(3): 402-427. DOI: https://doi.org/10.1007/s11747-015-0467-0

Chow, G.C. 1960. Tests of Equality Between Sets of Coefficients in Two Linear Regressions. Econometrica: Journal of the Econometric Society, 28(3): 591-605. DOI: https://doi.org/10.2307/1910133

Chumpitaz Caceres, R., \& Paparoidamis, N.G. 2007. Service Quality, Relationship Satisfaction, Trust, Commitment and Business-to-Business Loyalty. European Journal of Marketing, 41(7/8): 836-867. DOI: https://doi.org/10.1108/03090560710752429

De Vries, J., Schepers, J., Van Weele, A., \& Van Der Valk, W. 2014. When Do They Care to Share? How manufacturers make contracted service partners share knowledge. Industrial Marketing Management, 43(7): 1225-1235. DOI: https://doi.org/10.1016/j.indmarman.2014.06.015 


\section{The Effects of Competence-Based, Expressive and Collaborative Service Performance on the B2B Service Relationship Wenting Zou, Saara A. Brax, Risto Rajala}

Dillman, D.A. 2000. Mail and Internet Surveys: The tailored design method. Wiley, New York.

Doney, P.M., \& Cannon, J.P. 1997. An Examination of the Nature of Trust in Buyer-Seller Relationships, Journal of Marketing, 61(2): 35-51. DOI: https://doi.org/10.1177/002224299706100203

Eggert, A., \& Ulaga, W. 2002. Customer Perceived Value: a substitute for satisfaction in business markets? Journal of Business \& Industrial Marketing, 17(2/3): 107-118.

DOI: https://doi.org/10.1108/08858620210419754

Fornell, C., \& Larcker, D.F. 1981. Evaluating Structural Equation Models with Unobservable Variables and Measurement Error. Journal of Marketing Research, 18(1): 39-50.

DOI: https://doi.org/10.1177/002224378101800104

Grönroos, C. 1984. A Service Quality Model and its Marketing Implications. European Journal of Marketing, $\quad$ 18(4): $36-44$. DOI: https://doi.org/10.1108/EUM0000000004784

Guo, L., \& Ng, I. 2011. The Co-Production of EquipmentBased Services: An interpersonal approach, European Management Journal, 29(1): 43-50. DOI: https://doi.org/10.1016/j.emj.2010.08.005

Hair, J.F., Black, W.C., Babin, B.J., Anderson, R.E., \& Tatham, R.L. 2006. Multivariate Data Analysis. Upper Saddle River, NJ: Pearson Prentice Hall.

Handley, S.M., \& Benton Jr, W. 2009. Unlocking the Business Outsourcing Process Model. Journal of Operations Management, 27(5): 344-361. DOI: https://doi.org/10.1016/j.jom.2008.11.002

Hennig-Thurau, T. 2004. Customer Orientation of Service Employees: Its impact on customer satisfaction, commitment, and retention. International Journal of Service Industry Management, 15(5): 460-478. DOI: https://doi.org/10.1108/09564230410564939

Hennig-Thurau, T., Gwinner, K.P., \& Gremler, D.D. 2002. Understanding Relationship Marketing Outcomes an Integration of Relational Benefits and Relationship Quality. Journal of Service Research, 4(3): 230-247. DOI: https://doi.org/10.1177/1094670502004003006

Homburg, C., \& Garbe, B. 1999. Towards an Improved Understanding of Industrial Services: quality dimensions and their impact on buyer-seller relationships. Journal of Business-to-Business Marketing, $\quad 6(2): \quad 39-71$.

DOI: https://doi.org/10.1300/J033v06n02_02

Huo, B., Fu, D., Zhao, X., \& Zhu, J. 2016. Curbing Opportunism in Logistics Outsourcing Relationships: The role of relational norms and contract. International Journal of Production Economics, 182: 293-303.

DOI: https://doi.org/10.1016/j.ijpe.2016.07.005

Johnston, D.A., Mccutcheon, D.M., Stuart, F.I., \& Kerwood, H. 2004. Effects of Supplier Trust on Performance of Cooperative Supplier Relationships. Journal of Operations Management, 22(1): 23-38.
DOI: https://doi.org/10.1016/j.jom.2003.12.001

Kohtamäki, M., \& Rajala, R. 2016. Theory and Practice of Value Co-Creation in B2B Systems. Industrial Marketing Management, 56: 4-13. DOI: https://doi.org/10.1016/j.indmarman.2016.05.027

Lindberg, N., \& Nordin, F. 2008. From Products to Services and Back Again: Towards a new service procurement logic. Industrial Marketing Management, $\quad 37(3)$ : 292-300. DOI: https://doi.org/10.1016/j.indmarman.2007.07.006

Maramwidze-Merrison, E. 2016. Innovative Methodologies in Qualitative Research: Social Media Window for Accessing Organisational Elites for interviews. Electronic Journal of Business Research Methods, 14(2): 157-167. DOI: https://academicpublishing.org/index.php/ejbrm/article/view/1350

Morgan, R.M., \& Hunt, S.D. 1994. The CommitmentTrust Theory of Relationship Marketing. Journal of Marketing, $\quad$ 58(3): 20-38. DOI: https://doi.org/10.1177/002224299405800302

Oertzen, A.-S., Odekerken-Schröder, G., Brax, S.A., \& Mager, B. 2018. Co-Creating Services- Conceptual Clarification, Forms and Outcomes. Journal of Service Management, 29(4): 641-679. DOI: https://doi.org/10.1108/JOSM-03-2017-0067

Palmatier, R.W., Dant, R.P., \& Grewal, D. 2007. A Comparative Longitudinal Analysis of Theoretical Perspectives of Interorganizational Relationship Performance. Journal of Marketing, 71(4): 172-194. DOI: https://doi.org/10.1509/jmkg.71.4.172

Parasuraman, A., Zeithaml, V.A., \& Berry, L.L. 1985. A Conceptual Model of Service Quality and its Implications for Future Research. Journal of Marketing, 49(4): 41-50. DOI: https://doi.org/10.1177/002224298504900403

Parasuraman, A., Zeithaml, V.A., \& Berry, L.L. 1988. SERVQUAL: A Multiple-Item Scale for Measuring Consumer Perceptions of Service Quality. Journal of Retailing, 64(1), 12.

Rajala, R., Brax, S.A., Virtanen, A., \& Salonen, A. 2019. The Next Phase in Servitization: transforming integrated solutions into modular solutions. International Journal of Operations Production Management, $\quad 39(5):$ 630-657. DOI: https://doi.org/10.1108/IJOPM-04-2018-0195

Roberts, K., Varki, S., \& Brodie, R. 2003. Measuring the Quality of Relationships in Consumer Services: an empirical study. European Journal of Marketing, 37(1/2):

DOI: https://doi.org/10.1108/03090560310454037

Roehrich, J., \& Lewis, M. 2014. Procuring Complex Performance: implications for exchange governance complexity. International Journal of Operations \& Production Management, 34(2): 221-241. DOI: https://doi.org/10.1108/IJOPM-01-2011-0024 


\section{The Effects of Competence-Based, Expressive and Collaborative Service Performance on the B2B Service Relationship Wenting Zou, Saara A. Brax, Risto Rajala}

Roy, S.K., \& Butaney, G.T. 2014. Customer's Relative Loyalty: An empirical examination. Journal of Strategic Marketing, 22(3): 206-221. DOI: https://doi.org/10.1080/0965254X.2013.876074

Shamsollahi, A., Chmielewski-Raimondo, D.A., Bell, S.J., \& Kachouie, R. 2020. Buyer-Supplier Relationship Dynamics: a systematic review. Journal of the Academy of Marketing Science, 49(2): 418-436. DOI: https://doi.org/10.1007/s11747-020-00743-1

Selviaridis, K., \& Spring, M. 2007. Third Party Logistics: a literature review and research agenda. The International Journal of Logistics Management, 18(1): $125-150$.

DOI: https://doi.org/10.1108/09574090710748207

Selviaridis, K., Spring, M., \& Araujo, L. 2013. Provider Involvement in Business Service Definition: A typology. Industrial Marketing Management, 42(8): 1398-1410.

DOI:

https://doi.org/10.1016/j.indmarman.2013.07.019

Smeltzer, L.R., \& Ogden, J.A. 2002. Purchasing Professionals' Perceived Differences Between Purchasing Materials and Purchasing Services. Journal of Supply Chain Management, 38(4): 54-70. DOI: $\quad$ https://doi.org/10.1111/j.1745493X.2002.tb00120.x

Stauss, B., Nordin, F., \& Kowalkowski, C. 2010. Solutions Offerings: a critical review and reconceptualization. Journal of Service Management, 21(4): 441-459. DOI: https://doi.org/10.1108/09564231011066105

Tandon, U., Kiran, R., \& Sah, A.N. 2017. Customer Satisfaction as Mediator Between Website Service Quality and Repurchase Intention: An emerging economy case. Service Science, 9(2): 106-120. DOI: https://doi.org/10.1287/serv.2016.0159

United States Census Bureau. 2014. North American Industry Classification System [Online]. Available: http://www.census.gov/eos/www/naics/ [Accessed May 28 2015].

Vargo, S.L., \& Lusch, R.F. 2011. It's All B2B... and Beyond: Toward a systems perspective of the market. Industrial Marketing Management, 40(2): 181-187. DOI:

https://doi.org/10.1016/j.indmarman.2010.06.026

Zeithaml, V.A., Berry, L.L., \& Parasuraman, A. 1996. The Behavioral Consequences of Service Quality. Journal of Marketing, 60(2):31-46.

Zou, W., Brax, S.A., \& Rajala, R. 2018. Complexity in Product-Service Systems: review and framework. $\begin{array}{lll}\text { Procedia } & \text { CIRP, } & \text { 73(1): }\end{array}$ DOI: https://doi.org/10.1016/j.procir.2018.03.319

\section{About the Authors}

Wenting Zou, MSc (Tech), is a doctoral candidate at Aalto University, Finland. Her research focuses on managing the complexity of B2B services, paying a special attention to the influences of service contract management, contracting process, and service complexity on service providers' performance. Her work builds on an interdisciplinary background and combines multiple theoretical perspectives and methods of analysis. She is affiliated with Aalto University School of Science, Department of Industrial Engineering and Management.

Saara A. Brax, DSc (Tech), is a postdoctoral researcher at the School of Business and Management in LUT University, Finland. Her research covers service operations management and industrial management, focusing on servitization, industrial product-service systems, and service supply chains in the B2B context. Her recent works have focused on digitalization, data analytics and sustainability in supply chains.

Risto Rajala, DSc (Econ), is Associate Professor of Service Engineering and Management at Aalto University, Finland, and an Adjunct Research Professor at Carleton University, Canada. His research focuses on the management challenges of technology firms' service operations, including the management of complex service systems and the system-level changes linked with the transformation of technology industries toward service-based value creation. He currently serves as the Head of the Department of Industrial Engineering and Management of Aalto University.

Citation: Zou, W., Brax, S.A., Rajala, R. 2021. The Effects of CompetenceBased, Expressive and Collaborative Service Performance on the B2B Service Relationship. Technology Innovation Management Review, 11(5): 17-31. http://doi.org/10.22215/timreview/1439

Keywords: Service performance, Relationship performance, Repurchase intentions, B2B services, Business services, Service purchasing 